\title{
Doprinos kućnog kompostiranja zaštiti okoliša
}

\author{
Ivona Vidović \\ Odjel za Biotehnologiju \\ Sveučilište u Rijeci \\ Radmile Matejčić 2, Rijeka \\ vidovic.4ona@gmail.com
}

\author{
Lidija Runko Luttenberger \\ Studij politehnike \\ Sveučilište u Rijeci \\ Sveučilišna avenija 4, Rijeka \\ lidija.luttenberger@uniri.hr
}

\section{Sažetak}

Polazeći od činjenice da je kompostiranje prirodni proces biorazgradnje kojim nastaje humus, u radu je analiziran nastanak procesa kompostiranja i istaknuta njegova višestruka korist za biljni, životinjski svijet i za ljude. Naglašava se dobrobit komposta i u usporavanju globalnog zatopljenja, jer se poboljšanjem strukture tla, povećava i udio ugljika u njemu. Obrađene su osnovne faze koje se odvijaju u zemlji kako bi nastao kompost kao finalni proizvod, a prikazane su i okolnosti koje se mogu javiti prilikom samog procesa kompostiranja, poput neugodnih mirisa, prevelike vlažnosti ili suhoće zemlje i odviše prisutnih kukaca. Autori se zalažu za primjenu kućnog kompostiranja, čime se odvaja i smanjuje količina kućnog otpada, jer više od $30 \%$ otpada čini biootpad i naglašavaju da se kućnim kompostiranjem ujedno od otpada stvara vrijedan proizvod koji doprinosi plodnosti tla.

Ključne riječi: kućno kompostiranje; biootpad; biorazgradnja; humus.

\section{Uvod}

Kompostiranje je proces kojim se biootpad aerobno razgrađuje pri čemu nastaje ugljikov dioksid, toplina i kompost kao konačan produkt.

Proces kompostiranja bio je poznat već od davnina. Najraniji dokazi o počecima kompostiranja i poboljšavanja tla biootpadom sežu u drevno Akadsko carstvo koje je koristilo gnoj u agrikulturi već 2525 godina prije Krista
(University of Illinois, 2019). Danas, pored rastuće potrebe za plodnim tlom, pojavila se nužnost smanjenja stakleničkih plinova. Kao prijetnja svakodnevice izvire globalno zatopljenje, a rješenje bi ponuditi mogao upravo proces kompostiranja. Jedno od mjesta $s$ kojih se staklenički plinovi na dnevnoj bazi ispuštaju $u$ atmosferu su odlagališta.

Europska direktiva o odlagalištima (Council Directive, 1999) napominje potrebno smanjenje otpada koje se šalje na odlagališta na $35 \%$ do 
2020. za zemlje članice. Metan koji se ispušta u atmosferu $s$ odlagališta predstavlja najveću prijetnju u borbi protiv klimatskih promjena jer $u$ odnosu na ugljični dioksid skladišti i do 100 puta (NASA GISS, 2011) više topline. Toplina, jednom otpuštena u atmosferu, zagrijavanjem doprinosi topljenju ledenjaka i samim time i povećanju razine mora (European Commission, 2011).

Rad obrađuje proces aerobnog, toplog kompostiranja. Za razliku od anaerobnog, hladnog komposta, kod kojeg kao produkt nastaje metan i mogući su i različiti toksični spojevi, aerobno kompostiranje u prvi plan stavlja miješanje smjese u svrhu osiguranja dotoka kisika. Cilj rada je analiza kućnog kompostiranja s gledišta edukacije i osvješćivanja, a u svrhu isticanja njegova značaja, ne samo za društvo, već i za planet u cjelini.

\section{Višestruke dobrobiti kompostiranja}

Biootpad čini više od $30 \%$ kućanskog otpada te se kompostiranjem taj postotak može povratiti tlu umjesto da bude spaljen ili pak odložen na odlagališta, gdje znatno doprinosi ispuštanju stakleničkih plinova i dodatnom zagrijavanju atmosfere (US EPA, 2016).

Nakon svjetskih oceana koji su izvor 40.000 milijardi tona organskog ugljika, tla predstavljaju njegov drugi najveći depo sa zarobljenih 1.500 milijardi tona. Štoviše, više je ugljika spremljeno u zemlji negoli je u atmosferi (760 milijardi tona) i vegetaciji (560 milijardi tona) zajedno (European Commission, 2011).

Na slici 1 prikazana je zabrinjavajuća statistika iz 2015. (Hrvatska agencija za okoliš i prirodu, 2016) godine koja govori da je svega $2 \%$ ukupnog otpada u Hrvatskoj bilo kompostirano. Točnije, 27432 tona, dok je istovremeno količina odloženog komunalnog otpada iznosila 1.318 .740 tona. No, ipak, donekle je utješno što je $16 \%$, odnosno 132 tona, prošlo kroz neki oblik materijalne oporabe - primjerice, kroz dobivanje energije $u$ bioplinskim postrojenjima.
Za razliku od spaljivanja biootpada pri čemu se troši kisik iz zraka, ali i onemogućuje povratak hranjivih tvari u tlo, kompostiranje upravo omogućuje prirodan proces kruženja hranjivih tvari u prirodi tako što tlu vraća sve one sastojke koji su prvotno iz tla i dobiveni.

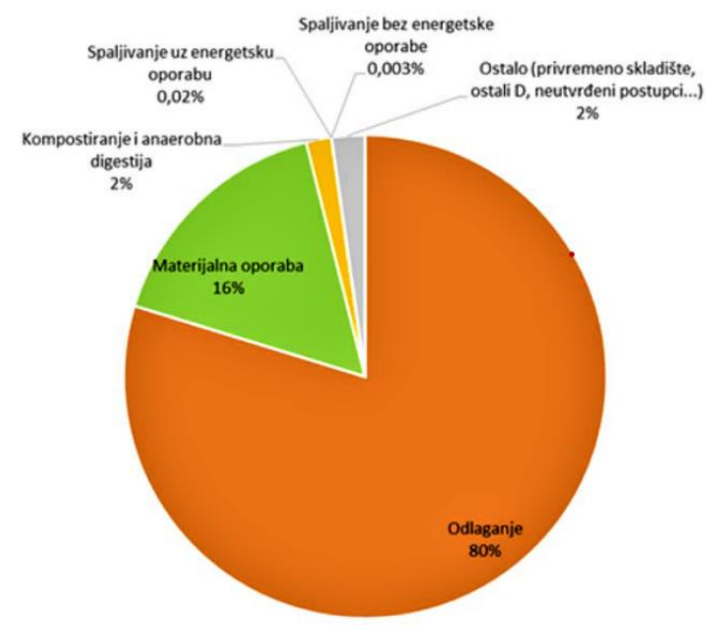

Slika 1. Udio postupaka oporabe/zbrinjavanja komunalnog otpada u 2015. godini (Hrvatska agencija za okoliš i prirodu, 2016)

Dodavanje gotovog komposta tlu vraća otpornost, čini ga plodnijim te ga regenerira. Tlo regeneracijom postaje prozračnije, povećava se mikrobiološka aktivnost tla, optimizira $\mathrm{pH}$ te $\mathrm{mu}$ se vraća vlažnost. To naposljetku doprinosi $i$ povratku močvarnih područja i cijelih novih biocenoza na tlo obogaćeno kompostom. Kako kompost tlo čini i plodnijim, na tlo bogato kompostom puno lakše će se rasprostraniti i ukorijeniti biljne vrste koje će poboljšati strukturu i raznovrsnost tla. Njihovim učvršćivanjem u tlo, korijenje bilja štiti tlo od erozije.

Nadalje, smanjeno je ispiranje hranjivih tvari iz tla. Preko ionskih interakcija kompleksi metala i soli (minerala) vežu se $s$ kompostnim česticama tako smanjujući prodor moguće štetnih kemijskih spojeva u vodene tokove (Yard Care Life website, 2019). Kako tlo postaje bogatije hranjivim tvarima i korisnim bakterijama tako ujedno djeluje i kao prirodno sredstvo protiv različitih biljnih $i$ 
životinjskih nametnika i štetočina namećući se patogenima kao kompeticija. Zato je dodavanje komposta tlu od mnogostruke koristi za cijeli biljni i životinjski svijet, a naposljetku i za ljudsko zdravlje u cjelini.

\section{Mikrobiološki tijek kompostiranja}

\subsection{Faze kompostiranja}

\subsubsection{Prva faza}

Prva faza (Beffa, 2002) je faza razgradnje u kojoj glavnu ulogu imaju mikroorganizmi, konkretnobakterije. Čak $90 \%$ komposta ove faze čine bakterije, aerobne i anaerobne. Smatraju se kemijskim razgrađivačima, jer su zaslužni za početnu razgradnju složenijih kemijskih spojeva u jednostavnije, poput organskih kiselina.

Kako je i po definiciji proces aeroban, tako i najveću ulogu imaju upravo aerobne bakterije. Aerobne se bakterije vrlo raznoliko hrane te im tvari bogate ugljikom služe kao energija, a one bogate dušikom kao građevna jedinica proteina $i$ nukleinskih kiselina. Procesom oksidacije ugljičnih spojeva one zagrijavaju kompostnu smjesu u odnosu na vanjsku temperaturu zraka.

Nekoliko je vrsta aerobnih bakterija u kompostu, ovisno o temperaturi koja prevladava. Psihrofilne bakterije prisutne su na najnižim temperaturnim rasponima, od $10-20^{\circ} \mathrm{C}$. U usporedbi s drugim tipovima bakterija, psihrofilne bakterije vrlo malo doprinose oslobađanju topline. No, zato, pripremaju uvjete za mezofilne bakterije, koje, djelujući na temperaturama od $20-40^{\circ} \mathrm{C}$ aktivno i ubrzano razgrađuju organske materijale na ugljikov dioksid i organske kiseline uz oslobađanje topline. Nakon što se temperatura kompostne smjese digne iznad $40^{\circ} \mathrm{C}$, mezofilne bakterije krenu umirati ili se pak primaknu vanjskim dijelovima hrpe. Potom su zamijenjene termofilnim bakterijama koje proces biorazgradnje nastavljaju sve do visokih $70^{\circ} \mathrm{C}$ po metru kubičnom. Visoka temperatura potrebna je kako bi uništila sjemenje korova, ali i uzročnike bolesti, patogene bakterije i protozoe. Osim toga, višim temperaturama omogućavaju se uvjeti za početak razgradnje proteina, masti i kompleksnih ugljikohidrata na finije čestice i njihove gradivne jedinice. Za bržu biorazgradnju poželjno je prozračivati kompostnu hrpu miješanjem kako bi se omogućio dostatan unos kisika.

Aerobnim bakterijama, za razliku od ljudi, nije potrebno punih $21 \%$ kisika iz zraka. One mogu preživljavati i u uvjetima u kojima dobivaju i niskih $5 \%$, no za njihovo neometano djelovanje preporuča se da se postotak kisika koji im je dostupan drži iznad 10\% (Tankeshwar, 2013).

Nakon što kroz par dana populacija termofilnih bakterija padne brojem, te se smjesa ohladi, mezofilne bakterije ponovno postaju dominantne i iako tada to ne znači da je kompost gotov, smanjenje temperature označava novu, daljnju progresiju razgradnje u kojoj se uključuju i neki višestanični mikroorganizmi.

\subsubsection{Druga faza}

Uz različite mikroorganizme poput mezofilnih bakterija u kompostnoj se smjesi prvi puta pronalaze i aktinomicete, koje predstavljaju prijelaznu fazu između bakterija i gljiva (kvasci, plijesni). One su zaslužne da krajnji produkt nosi miris „šumske zemlje“, ali jednako tako i za razgradnju otpornijih materijala u smjesi. To su, primjerice, lignin iz drveta, celuloza, škrob i proteini. Kako dolazi do redukcije materijala, tako se oslobađaju i elementi poput dušika, ugljika i amonijaka čime hranjivi sastojci postaju dostupni za više organizme.

Osim bakterija i aktinomiceta, i gljive su vrlo zaslužni i vrlo poznati razlagači. One također pospješuju daljnju razgradnju teže razgradivih spojeva koji mogu proizlaziti iz stapki, grančica, iglica i slično, a odgovaraju im niže temperature i niži $\mathrm{pH}^{1}$ koji je uspostavljen prvotnom razgradnjom organskih kiselina od strane bakterija.

\subsubsection{Treća faza}

\footnotetext{
${ }^{1}$ Temperature do $25^{\circ} \mathrm{C} \mathrm{i} \mathrm{pH} \mathrm{od} \mathrm{oko} 7$.
} 
Ovu fazu karakterizira daljnja, većinom probavna razgradnja od strane makroorganizama. Točnije, grinja, stonoga, puževa, pauka, kukaca, mrava, buha, a posebice oblića, crvi i glista. Oni se smatraju fizičkim razgrađivačima budući da melju, grizu, sisaju, trgaju i žvaču materijale na sitnije komade koji su lakše probavljivi za sitnije mikroorganizme.

Kompostne kuglice koje nastaju probavom, a čine izmet višestaničnih organizama ponovno ulaze $u$ daljnju obradu od strane bakterija, tako uzrokujući ponovno oslobađanje hranjivih tvari i zatvaranje kruga u hranidbenom lancu. Grudice koje nastaju probavom višestaničnih organizama, a kasnije se još dorađuju nižim organizmima čine finalni produkt-kompost koji je u procesu vrućeg kompostiranja za nekoliko mjeseci spreman za uporabu u vrtu.

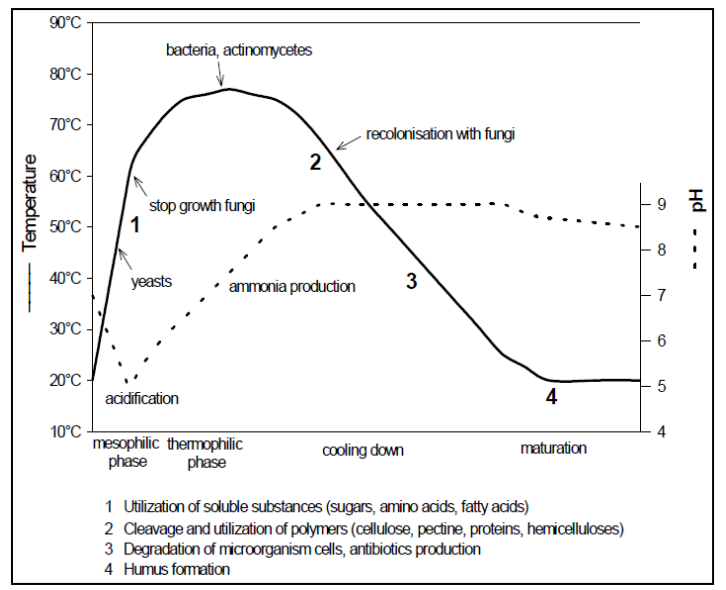

Slika 2. Shematski prikaz procesa kompostiranja (Beffa, 2002)

Faze kompostiranja prethodno opisane prikazane su na Slici 2. Sažeto, prva faza (20$40^{\circ} \mathrm{C}$ ) okarakterizirana je bakterijama koje zakiseljavaju tlo, a za ulogu imaju razgradnju topljivih tvari poput šećera, amino kiselina i masti. Aktinomicete nisu efektivne sve dok je nutritivna vrijednost visoka, ali zato imaju veliku ulogu na temperaturama iznad $40^{\circ} \mathrm{C}$ kada iskorištavaju polimere poput celuloze, pektina i proteina. Nastup mezofilnih i termotoleratnih bakterija označava zadnje korake u formaciji komposta, odnosno humusa. Tada slijede i neki od najvažnijih procesa u prirodi poput fiksacije atmosferskog dušika stvaranjem amonijaka, nitrata, a potom i nitrifikacijom bakterija. Nadalje, odvija se mineralizacija željeza, mangana i fosfora, vezanje metala ( $\mathrm{Na}+, \mathrm{Mg} 2+, \mathrm{Cu} 2+, \mathrm{Ca} 2+, \mathrm{K}+\ldots)$ i formacija mineraliziranih nakupina, te naposljetku, detoksikacija vezanjem teških metala i formiranjem netopljivih soli, te razgradnja toksičnih organskih spojeva poput pesticida (Beffa, 2002).

\subsection{Proces kompostiranja}

Za smještaj kompostera nije potrebno niti puno mjesta, ali niti resursa. Danas su na tržištu dostupne razne kućne varijante. Raspon seže od ugradbenih do onih na miješanje, ili pak u nestašici prostora - balkonskih, koji se temelje na crvima, a stvaraju tekući fertilizator i zauzimaju prostor veličine teglice biljke. Najpraktičnije i najjednostavnije rješenje može se postići ograđivanjem željenog vrtnog prostora $s$ par paleta, drvenih daski, žicom ili ciglama.

U takav prostor zbog prozračnosti i drenaže na dno se prvo stavlja sloj granja kako je prikazano na Slici 3. Potom se samo nižu slojevi kućanskog biootpada tako da se treba paziti na omjer suhih $\mathrm{i}$ vlažnih tvari. Optimalno, suhih treba biti u suvišku u odnosu na vlažne tvari. Odnosno, na jednu kantu vlažnih idu dvije kante suhog materijala.

Taj omjer zove se ugljik : dušik omjer. Kako su u većini organskih tvari ovi elementi prisutni (ugljik u svima, dušik u većini ${ }^{2}$ ), stvar je samo njihovog omjera koji čini razliku u uvjetima kompostne smjese. Obično suše i smeđe tvari označavaju tvari s niskim koncentracijama dušika, a visokim ugljika. To su primjerice, osušena trava, lišće, uvelo cvijeće, korov, usitnjeno granje, piljevina, sijeno, slama, pepeo drvenog ugljena ili drva, usitnjeni papir, neobojani karton, peleti i slično.

Primjerice, omjer u lišću je od 30-80 atoma ugljika na jedan atom dušika ili pak u drvnoj sječki, C:N omjer je 500-700:1 (University of Illinois, 2019). Omjer je dobro održavati u rasponu 25-30:1, što se omogućava dodavanjem vlažnih

${ }^{2}$ Dušik je prisutan u onim organskim tvarima koje sadržavaju proteine ili nukleinske kiseline. Primjer izvora proteina $u$ bakterija su enzimi koji su nužni za njihov metabolizam. 
sastojaka koji će izbalansirati visok postotak ugljika u suhim spojevima. To su na primjer sirovi ostaci povrća, kora krumpira, ostaci voća, usitnjena kora agruma, talog kave, ostaci čaja, ljuske jaja, kokošji ili goveđi stajnjak i slično.

Za razliku od suhih tvari koje osiguravaju izvor energije mikroorganizmima, ali i usporavanje razgradnje i prozračnost smjese, materijali bogati dušikom pak predstavljaju građevne jedinice za nukleinske kiseline $i$ proteine nužne za metabolizam mikro i makro organizama.

Nakon što se doda potrebna količina suhe $i$ vlažne tvari svakih deset dana korisno je smjesu i promiješati grabljama jer će to omogućiti brži proces stvaranja konačnog komposta (Guo i sur., 2012). Kompostna zemlja, humus, može se prepoznati po svojoj specifičnoj tamnosmeđe do crnoj boji, slatkastom mirisu „šumske zemlje“, rahloj, grumenastoj, prhkoj, na dodir prozračnoj strukturi. Ovisno o vrsti i količini kompostiranog materijala i uvjetima kompostiranja, u roku od 6 do 12 mjeseci od biorazgradivog otpada nastaje kompost.

Nezreli kompost nema tamnu boju, kiselkastog je mirisa ili miriše na gljive. U njemu se mogu naći ostaci lako razgradivih tvari poput lišća, ostataka povrća i sl. Takav kompost mora još neko vrijeme odležati (Čistoća Dubrovnik, 2016).

\section{KOMPOSTNA HRPA}

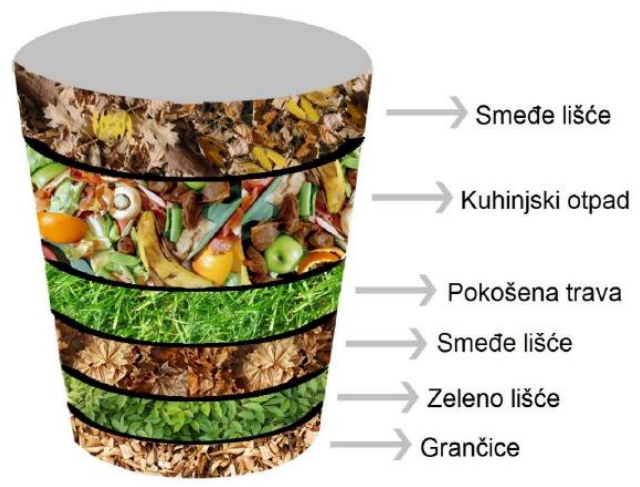

Slika 3. Slojevi biootpada u komposteru

\section{Dostizanje željenih rezultata}

Da bi se kompost što prije stvorio, potrebno je pripaziti na pojedine uvjete pod kojim je komposter održavan.

Jer, na umu je uvijek dobro imati da se brigom oko parametara kao što su vlažnost, temperatura i usitnjenost biootpada, zapravo brinemo o održanju cijelog jednog hranidbenog lanca $u$ malom na životu. Svako odstupanje od idealnih uvjeta uglavnom rezultira sporijim procesom razgradnje (How to Compost, n.d.).

\subsection{Tvari koje ne pogoduju kompostiranju}

Tvari koje nije preporučljivo stavljati u komposter na biorazgradnju su sljedeće: osjemenjene korove, lišće oraha, bolesne biljke, otpatke kuhanih jela, meso i mesne i životinjske prerađevine, mliječne proizvode, kosti, velike količine novinskog papira, časopise $u$ boji, pelene, izmet kućnih ljubimaca, ostatke duhana, ulja i tvari s uljnim premazima, sadržaj vrećice usisavača i pepeo kamenog ugljena.

Osjemenjeno korijenje nije dobro dodavati jer je po njihovoj prirodi uobičajeno da se učvrste $u$ tlo i po mogućnosti rastu. To, osim što će oduzimati potrebne hranjive tvari kompostu također će i učiniti okretanje kompostne smjese puno težim. Također, dodavanjem bolesnog lišća bespotrebno kompost stavljamo u rizik od kontaminacije štetočinama.

Nije preporučljivo dodavati niti lišće oraha (Laidback Gardener, 2015) koje je poznato po ispuštanju spoja toksičnog za druge biljke, juglona. Zapravo, orahovo korijenje tako "truje“ zemlju oko sebe kako bi onemogućilo drugim biljkama da se rasprostrane na teritorij koji trenutačno zauzima-orah.

Nadalje, zbog spore i teške razgradnje-nije preporučljivo odlagati ni: čepove od pluta, ljuske oraha, češera i cijele grančice i stapke. Pelenama i životinjskim izmetom te maramicama s fiziološkim izlučevinama moguć je unos pesticida, patogenih virusa i bakterija, antibiotika kao i sa spojeva koji su prošli ljudsku ili životinjsku biotransformaciju 
kako bi se izlučili iz tijela. To su nerijetko toksične i štetne tvari za ljudski organizam, ali i za biljni i životinjski svijet koji im je time izložen, a najčešće bez razvijenih, prijeko potrebnih, mehanizama kojim bi se protiv istih borio.

Zanimljivo da sadržaj usisavača, koji naizgled može sadržavati samo prašinu i dlake također nije preporučljivo dodavati kompostu. Tome je tako jer, vrlo najvjerojatnije postoje ostaci deterdženta ili pak mikroplastike koji mogu pogubno djelovati na višestanične organizme poput crva (Boots, Russell, Green, 2019) koji su izuzetno osjetljivi na ono čime su hranjeni.

Općenito, treba izbjegavati dodavanje otpadaka koje sadrže kemikalije, primjerice, stare lijekove, plastičnu ambalažu, bojano impregnirano drvo i stiropor.

\subsection{Smještaj kompostera i regulacija vlažnosti}

Kako bi se komposter zaštitio od nepredviđenih klimatskih uvjeta, preporučljivo ga je držati u sjenovitom, skrovitom kutku vrta koji je zaštićen od padalina i direktnog udara sunca. Iz tog razloga dobro je imati poklopac na samom komposteru što će onemogućava da padaline remete vlažnost kompostne smjese ili da sunce povisi temperature koje su specifične za pojedinu fazu razgradnje. Treba izbjegavati mračna, hladna i previše vlažna mjesta.

Jako je važno da je kompostna hrpa u izravnom dodiru s tlom ${ }^{3}$ kako bi organizmi, posebice višestanični, mogli imati nesmetan pristup kompostištu.

Ukoliko na komposteru ne postoji poklopac, vlažniji materijal uvijek je dobro prekriti sušim, poput zemlje, sloja mahovine, sjena, slame, kartona ili usitnjenog papira i potom sve skupa prekriti i vrećom od kakvog prirodnog materijala, poput jute. Suhi materijal upit će suvišnu vlagu, a primjerice jutena vreća, osim prozračnosti očuvat će i izvornu temperaturu kompostne smjese svake faze.

${ }^{3}$ Osim ako se ne radi o anaerobnoj dekompoziciji, ne smještati komposter na tvrde/umjetne podloge, beton, kamen i slično.
Suhoća se često javlja u ljetnim mjesecima zbog isparavanja pri visokim temperaturama. Taj se problem može izbjeći primjenom ledene boce vode obmotane papirom koja će tako regulirati previsoke temperature koje mogu naštetiti organizmima i usporiti kompostiranje. Uz to, kompost se može pošpricati vodom, no treba biti oprezan da se ne pretjera jer previše vode može vrlo lako zatvoriti zračne prolaze i dovesti do ugibanja organizama kojima je potreban zrak.

Ukoliko se iz grumena zemlje voda cijedi, to je indikator da je hrpa odviše vlažna te je potrebno kompostnu hrpu preokrenuti i dodati materijal koji upija suvišnu vlagu, primjerice piljevinu, suho lišće, sjeckani papir, kartonske kutije od jaja i slično.

Iskustveno, vlažnost u kompostu treba biti slična onoj iscijeđene spužve, oko 45-60\% (Bilsens Brolis, 2019). Vlažnost komposta se može provjeriti tako da se iz dubine hrpe uzme šaka kompostnog materijala i lagano se stisne. Ako iz šake curi tekućina, previše je vode. Ako se u stisnutoj šaci ne osjeća vlažnost, vode nedostaje. Kada materijal u šaci ostaje zbijen u grudi, vlažnost je primjerena.

\subsection{Izbjegavanje neugodnih mirisa}

Hrpu je nužno povremeno, a barem jednom mjesečno, preokrenuti. Proces miješanja osigurava prozračivanje jer je zrak neophodan za rast i razvitak organizama u kompostu, istovremeno sprječavajući stvaranje neugodnih mirisa. Uz to, hrpa se ne smije prilikom miješanja zbijati, kako bi se omogućilo nastajanje rahlog $\mathrm{i}$ prhkog komposta.

Neugodni mirisi mogu nastati u situacijama nedostatnog dotoka kisika ili suviška dušika. Ukoliko je omjer niži od 30:1 ugljik naprama dušik, u većini slučajeva dolazi do stvaranja neugodnih mirisa jer dušik iz kompostne smjese izlazi $u$ obliku amonijaka. Neugodnim mirisima može doprinijeti i razvoj anaerobnih bakterija $u$ nedostatku kisika. Uvjeti će pogodovati razvijanju nusprodukata razgradnje poput sumporovodika. Rješenje je preokretanje kompostne hrpe za omogućavanje prozračivanja i nadodavanje suhog materijala za upijanje viška vlage (npr. 
grančice, suho lišće). Ukoliko nam suho lišće ili piljevina primjerice, nisu dostupni, može se iskoristiti isjeckani papir. ${ }^{4}$

\subsection{Povećana količina životinja}

Kukci imaju važnu ulogu u kompostiranju. Kao što je ranije naglašeno, komposter zapravo predstavlja hranidbeni lanac u malom što se zorno može vidjeti i na slici 4. (Math Science Nucleus, 2015). Sastavljen je od primarnih proizvođača, autotrofnih zelenih biljaka čiji je rast pospješen kompostom, zatim potrošača prvog, drugog i trećeg reda, heterotrofnih organizama, ali i razlagača koji će organsku tvar razgrađivati na jednostavne anorganske spojeve-vodu, ugljikov dioksid i mineralne soli vraćajući ih staništu za daljnje korištenje biljkama.

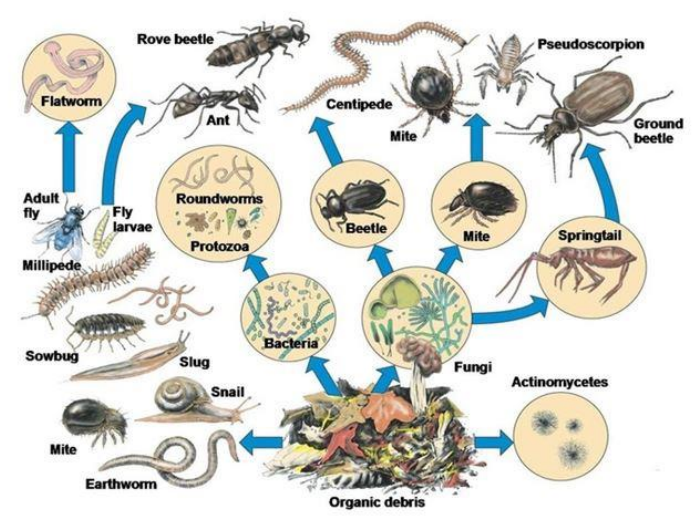

Slika 4. Sudionici hranidbenog lanca

Konzumenti prvog reda hrana su konzumentima drugog, a oni drugog, onima trećeg. Tako se gnjide i skokuni ${ }^{5}$ hrane saprofitima, gljivama. Sićušni kornjaši hrane se sporama gljivica. Nematode ${ }^{6}$ probavljaju

${ }^{4}$ Kako bi uvijek pri ruci imali suhog materijala dobro je u jesen razmišljati o skladištenju pograbljanog lišća i drveta za opskrbu suhim materijalom tijekom godine.

${ }^{5}$ Eng. springtails

6 Oblići, zool. razred beskralješnjaka nesegmentirana tijela (Nematodes), nemaju krvotok ni dišne organe, većinom su paraziti (bijela glista Oxyuris vermicularis, dječja glista Ascaris lumbricoides, čovječja glista Trichuris trichiura) (“Hrvatski jezični portal," n.d.) bakterije. Protozoe i kolnjaci ${ }^{7}$ prisutni u vodenim filmovima hrane se bakterijama i biljnim česticama, ostacima. Grinje predatori i pseudoškorpioni vrebaju kao plijen nematode, ličinke muha, druge grinje i skokune. Crvi plošnjaci gutaju puževe, nematode i kolnjake. Konzumenti trećeg reda poput stonoga, gusjenica, kornjaša i mrava hrane se konzumentima drugog reda (University of Illinois, 2019). Nakon što konzument ugine, njegovo tijelo ponovno se razgrađuje na osnovne sastojke koji će hraniti ili niže ili direktno-bez potrebne razgradnje-više organizme. I tako u krug.

Ukoliko je pak vidno odviše kukaca ili insekata poput muha, moguće da je u kompostu prisutna hrana koja je teško razgradljiva-poput mesa ili mliječnih proizvoda, kosti ili ulja koji mogu privući i veće glodavce, poput miševa, štakora i slično.

\subsection{Produljeno vrijeme razgradnje}

Ukoliko proces kompostiranja nema vidljivih znakova života poput topline kompostne hrpe, ponekad je za uspješne uvjete potrebno dodati tvari poput aktivatora. To su na primjer, goveđi i kokošji gnoj, koštano brašno, čajne vrećice, talog od kave, šećer ili med razmućen u vodi i slično. Kompost možda nema dovoljno energije $i$ hranjivih tvari za procese biorazgradnje $\mathrm{i}$ tada tvari koje se dodaju predstavljaju brz pristup energiji i nutritivnim sastojcima.

Kako proces biorazgradnje do završnog komposta $u$ anaerobnom procesu traje od 9-12 mjeseci, a u aerobnom nekolicinu, dobro je oboružati se strpljenjem. Ukoliko niti nakon dužeg vremena na kompostnoj smjesi nije vidljiva promjena, nekoliko je parametara koji su mogli utjecati na usporavanje procesa razgradnje.

Jedan od njih je hladnoća. Za hladnog vremena živi organizmi, bakterije, manje su aktivne pa treba i to uzeti u obzir. Dodavanje biomase (dušika) i miješanje te pokrivanje smjese suhim materijalom pomoći će da mikroorganizmi uvijek imaju dovoljno goriva koje će pretvarati u toplinu.

\footnotetext{
${ }^{7}$ Eng. rotifers
} 
Do usporenog stvaranja komposta može doći i zbog komponenti komposta koji su teže razgradivi, poput stapki, grančica, stabljika, iglica i sličnih biljnih komponenti u kojima je lignin isprepleten celuloznim vlaknima što razgradnju čini puno sporijom.

Dodatno, veličina tvari također igra ulogu. lako je primjerice, jednaka masa drvne sječke $\mathrm{i}$ piljevine, piljevina će se brže razgraditi jer zbog veće površine koju piljevina zauzima stavlja više volumena ugljika na raspolaganje mikroorganizmima koji im je tako, lakše dostupan za korištenje.

\section{Zaključak}

lako je proces kompostiranja poznat od davnina, danas je taj postupak sve više aktualan. Upravo postupak kompostiranja doprinosi podizanju kvalitete tla i postizanju ciljeva smanjenja količine stakleničkih plinova kroz zadržavanje njihovih glavnih komponenti, ugljika i dušika u tlu.

Prednost postupka je da se jednostavno provodi, jer je prirodni proces razgradnje spontan. Pri tome, stjecanje iskustva provoditelja kompostiranja vrlo brzo dovodi do boljeg razumijevanja i shvaćanja značaja te mikro zajednice koju je potrebno održavati na životu iako se ona u suštini sama održava.

Uz mogućnost praćenja prirodnih procesa stvaranja i razgradnje, povećanjem stope kompostiranja u kućanstvima može se znatno smanjiti i količina otpada odloženog na odlagališta, a time i emisija metana, plina koji predstavlja najveću opasnost za zagrijavanje atmosfere.

Autori preporučuju primjenu kućnog kompostiranja jer više do $30 \%$ kućnog otpada čini biootpad koji se tim postupkom vraća u prirodu i povećava otpornost tla, pa je $u$ tome vidljiva $i$ višestruka korist za zajednicu.

Takvim djelovanjem svaki građanin može pridonijeti višem cilju, a to je praktična dobrobit $\mathrm{i}$ održanje temperature na Zemlji u rasponu prihvatljivom za ekosustave i ljude.

\section{Literatura}

Anaerobic Digestion and Composting. (n.d.). Retrieved May 11, 2019, from Carry on Composting website: http://www. carryoncomposting.com/142941479

Beffa T. (2002). The composting biotechnology: A microbial aerobic solid substrate fermentation complex process. The composting process and management. Madep, USA.

Bilsens Brolis, L. (2019). Community Composting Done Right: A Guide to Best Management Practices. Preuzeto sa https://ilsr.org/composting-bmp-guide.

Boots, B., Russell, C. W., Green, D. S. (2019). Effects of Microplastics in Soil Ecosystems: Above and Below Ground. Environmental Science \& Technology, 53(19), 11496-11506. https://doi.org/10.1021/acs.est.9b03304.

Can you compost walnut leaves? - Laidback Gardener. (n.d.). Retrieved May 11, 2019, from https://laidbackgardener.blog/tag/canyou-compost-walnut-leaves/

Community Composting Done Right: A Guide to Best Management Practices. (2019, March 28). Retrieved October 1, 2019, from Institute for Local Self-Reliance website: https://ilsr.org/composting-bmp-guide/

Council Directive 1999/31/EC of 26 April 1999 on the landfill of waste. , Pub. L. No. 31999L0031, OJ L 182 (1999).

Čistoća Dubrovnik. (2016, October 18). Brošure i letci. Retrieved May 14, 2019, from Čistoća Dubrovnik website: https://cistocadubrovnik. hr/edukativni-kutak/vodiči-o-odvajanju-i-kom postiranju.html

European Commission (2011). Soil: The Hidden Part of the Climate Cycle. Preuzeto 01. 10. 2019 sa https://ec.europa.eu/clima/sites/ clima/files/docs/soil and climate en.pdf. 
Food_chain_decomposers. (n.d.). Retrieved May 14, 2019, from https://msnucleus.org/membe rship/ngss/fourth ngss/04food chain decom posers.html

Guide To Composting: How To Start \& Make a Compost Pile at Home. (2019, January 11). Retrieved May 11, 2019, from Yard Care Life website: https://www.yardcare.life/how-tostart-make-a-compost-pile-at-home/

Guo, R., Li, G., Jiang, T., Schuchardt, F., Chen, T., Zhao, Y., Shen, Y. (2012). Effect of aeration rate, $\mathrm{C} / \mathrm{N}$ ratio and moisture content on the stability and maturity of compost. Bioresource Technology, 112, 171-178. https:// doi.org/10.1016/i.biortech.2012.02.099.

HAOP. (2016, 2017.). Retrieved October 23, 2019, from HAOP website: http://www.haop.hr/hr

History of Composting-Composting for the Homeowner-University of Illinois Extension (2019). Preuzeto 08. 05. 2019. sa https://web.extension.illinois.edu/homecomp ost/history.cfm.

Hrvatska agencija za okoliš i prirodu (2016). Stanje gospodarenja otpadom u Republici Hrvatskog. Preuzeto sa http://www.haop.hr

Hrvatski jezični portal (2018). Preuzeto 29. 11. 2018 sa http://hjp.znanje.hr

Laidback Gardener (2015). Can you compost walnut leaves? Preuzeto 11. 05. 2019 sa https://laidbackgardener.blog/tag/can-youcompost-walnut-leaves/.

Math Science Nucleus (2019). Preuzeto sa https://msnucleus.org/membership/ngss/four th_ngss/04food_chain_decomposers.html.

NASA GISS: News Q\&A: Cleaning the Air Would Limit Short-Term Climate Warming. (n.d.). Retrieved May 8, 2019, from https://www.giss.nasa.gov/research/news/20 $\underline{110220 /}$

Odluka o donošenju Plana gospodarenja otpadom Republike Hrvatske za razdoblje 2017. - 2022. Godine (2017). Preuzeto 14. 05. 2019. sa https://narodne-novine.nn.hr
Soil: The Hidden Part of the Climate Cycle European Commission. Environment Directorate-General-Google Knjige. (n.d.). Retrieved October 1, 2019, from https://books.google.hr/books/about/Soil.ht $\underline{\mathrm{ml} \text { ?id=f76CnQAACAAJ\& redir esc }=y}$

Tankeshwar (2013). Oxygen Requirements for Pathogenic Bacteria. Preuzeto 30. 09. 2019 sa Microbeonline website: https:// microbeonline.com/oxygen-requirements-forpathogenic-bacteria/

Team, F. (2017, July 5). Extreme sea levels on the rise along Europe's coasts [Text]. Retrieved October 23, 2019, from EU Science HubEuropean Commission website: https://ec.europa.eu/jrc/en/publication/extre me-sea-levels-rise-along-europe-s-coasts

The Science of Composting-Composting for the Homeowner-University of Illinois Extension. (n.d.). Retrieved May 8, 2019, from https://web.extension.illinois.edu/homecomp ost/science.cfm

University of Illinois (2019). The Science of Composting - Composting for the Homeowner. University of Illinois Extension. Preuzeto $08.05 .2019 . \quad$ sa https://web.extension.illinois.edu/homecomp ost/science.cfm.

US EPA, O. (2016, April 15). Basic Information about Landfill Gas [Overviews and Factsheets]. Retrieved May 8, 2019, from US EPA website: https://www.epa.gov/Imop/basic-information -about-landfill-gas

Yard Care Life website (2019). Guide To Composting: How To Start \& Make a Compost Pile at Home. Preuzeto 11. 05. 2019 sa https://www.yardcare.life/how-to-start-makea-compost-pile-at-home 


\title{
The contribution of home composting to environmental protection
}

\begin{abstract}
Given that composting represents a natural process of biodegradation the product of which is humus, the paper analyses the onset of composting process and highlights its numerous benefits for flora, fauna and humans. Emphasized is the role compost has in reducing the effects of global warming through improving soil structure and the amount of carbon captured in it. Basic stages are described that take place in the soil the output whereof is compost, and issues that can arise during the composting process are listed, such as odours, excessive humidity or dryness of soil, and disproportionate presence of insects. The authors advocate implementation of home composting by which separation and reduction of volumes of municipal waste are achieved as biowaste makes more than $30 \%$ of municipal waste and also point out that home composting results in a valuable product which contributes to soil fertility.
\end{abstract}

Keywords: home composting; bio-waste; biodegradation; humus. 